
КОМПОНЕНТІВ СТРУКТУРИ ЛЮДСЬКОГО КАПІТАЛУ

\author{
Benko N.M., \\ applicant of the third educational and scientific \\ level of higher education in the specialty \\ 051 "Economics", EP "Economics", \\ National Academy of Management, Kyiv
}

\title{
CONTENT CHARACTERISTICS AND ASPECTIZATION OF COMPONENTS OF HUMAN CAPITAL STRUCTURE
}

Постановка проблеми. В сучасних умовах господарювання конкурентоспроможність економіки України на світовому ринку може бути досягнута тільки стабільними темпами переходу до інноваційної моделі, у якій центральне місце займає людський капітал. Тому фрормування, на рівні сучасних вимог, людського капіталу є однією з актуальних проблем суспільно-економічного розвитку країни. Вирішення цієї проблеми можливе шляхом інвестування в людину та розвиток ії здібностей для забезпечення основи стійкого економічного зростання. В теоретичному обґрунтуванні розвитку людського капіталу відчувається потреба його ідентифрікації як принципово важливого джерела економічного зростання та аспектизації компонент його структури.

Аналіз останніх досліджень і публікацій. Перспектива дослідження людського капіталу, як стратегічної складової економічного розвитку, має давні історичні корені. Перші формулювання, специфрічні особливості людського капіталу спостерігаються у У. Петті, А. Сміта, А. Маршалла, К. Маркса, У. Фарра, Е. Енгеля, Т. Вітстейна, Д. С. Мілля та багатьох інших вчених.

Внесок у розвиток сучасної теорії людського капіталу зробили Т. Шульц, Г. Беккер, Д. Мінцер, Б. Вейсброд, Е. Денісон, Р. Солоу, Дж. Кендрік, Х. Боуен, Л. Тороу, М. Блауг, С. Фішер, Р. Дорнбуш, P. Шмалезі та інші економісти, соціологи та історики.

Розвитком теорії людського капіталу займались такі російські науковці, як: Ю. Корчагін, 3. Глухова, Є. Кукліна, Є. Єгель, А. Дєтков, В. Бончакова, П. Жихалов, С. Гусєва, Т. Баландіна, К. Княгініна, Ю. Хайрулліна, Е. Шульгіна та інші.

Дуже корисними виявилися результати досліджень українських вчених: О. Амосов, А. Дєгтяр, Г. Яловий, А. Сігайов, О. Шинкарюк, О. Риковська, О. Лелюк, В. Компанієць, В. Ковальова, О. Каменська, Т. Ящук, А. Шахно, Н. Ушенко, О. Левчук, Д. Мельничук, Н. Марущак та багато інших.

Вивчення результатів досліджень дозволило зробити висновок про необхідність систематизації та подальшої розробки підходів до сутності людського капіталу, компонентів його структури та показників, що характеризують його як інтенсивний чинник розвитку економіки знань.

Постановка завдання. Метою статті є узагальнення різноманітних підходів до трактування сутності і значення людського капіталу для розробки сучасного теоретичного підґрунтя розвитку людського капіталу економіки країни. Для досягнення мети було поставлено завдання дослідження сутності людського капіталу та його фрормалізації у капіталі загалом через компоненти та схеми формування людського капіталу, рівні, внутрішню структуру, типи людського капіталу для потреб управління національною економічною системою.

Виклад основного матеріалу дослідження. Інтерес до людського капіталу (human capital), як стратегічної складової економічного розвитку, обумовлений корінними змінами, що відбуваються в економіках країн під впливом науково-технічної та інформаційної революції. Саме людський капітал, який втілює творчий потенціал людини у всьому його розмаїтті, стає вирішальним фрактором соціального та економічного прогресу, тому що містить сукупність якостей, які 
визначають продуктивність і можуть стати джерелами доходу для людини, сім'ї, підприємства і суспільства.

Отже, виділення фрактора «людський капітал», як відзначає професор Яловий Г. К., дає можливість ідентифікувати принципово важливе джерело економічного зростання, яким є знання, компетенція, і відповідно, позитивно визначити економічну роль освіти, науки, охорони здоров'я та інших нематеріальних галузей людської діяльності у розвитку людського капіталу [16, с. 20].

Дослідження проблематики людського капіталу як фрактора економічного і соціального розвитку (прогресу) спричинило виникнення теорії людського капіталу, яка на сьогоднішній день $€$ концептуальною базою для розробки стратегії розвитку і використання людських ресурсів. Людський капітал, так само як виробничий, фінансовий, має велике, а за окремими оцінками й вирішальне значення у процесі відтворення суспільного продукту.

Теоретичний аналіз літератури дозволяє дійти висновку, що теорія людського капіталу заснована на положеннях інституціональної, неокласичної, неокейнсіанської та інших економічних теорій, які визнають ту обставину, що для суспільства люди представляють собою такий самий капітал, як і засоби виробництва. Крім того, теорія людського капіталу вивчає процес якісного вдосконалення людських ресурсів, утворивши таким чином один із центральних розділів сучасного аналізу пропозиції праці.

Заслуга виникнення теорії людського капіталу, як самостійного розділу економічного аналізу, належить Т. Шульцу та Г. Беккеру, які розвинули ідею людського капіталу, обґрунтувавши ефективність вкладень у людський капітал і сформулювавши економічний підхід до людської поведінки. Під поняттям людський капітал вчені розуміли сукупність якостей, навичок, здібностей і знань людей, які ними використовуються у виробничих, з метою отримання майбутнього доходу, або (та) майбутніх споживчих цілях. Саме тому він (людський капітал) і є капіталом [1; 2; 4, с. 28]. Т. Шульцу і Г. Беккеру належить заслуга популяризації ідеї людського капіталу. Їх зусилля дали поштовх численним дослідженням і ініціювали активну діяльність по мотивації інвестицій у професійну та технічну освіту з боку міжнародних фінансових інститутів. Цьому сприяли результати статистичних спостережень динаміки зростання національних економік економічно розвинених країн. Статистичні спостереження переконливо засвідчили, що реальне економічне зростання випереджає розрахунки, які базуються на врахуванні класичних чинників зростання - кількісних факторів виробництва (праці та капіталу), що дало змогу визначити людський капітал як основний фрактор розвитку суспільства і економіки, а також розшарування суспільства за рівнями отриманих доходів.

Для розробки сучасного теоретичного підґрунтя людського капіталу надзвичайно актуальними є питання дослідження та чіткого фрормулювання сутності людського капіталу та його формалізації у капіталі загалом, через компоненти та схеми фрормування людського капіталу, рівні, внутрішню структуру, систему показників, типи людського капіталу для потреб управління національною економічною системою.

У аналітичній доповіді Центру Разумкова, що опублікована у 2018 році, зазначається, що в умовах ринкової економіки багато явищ і процесів набувають товарної і грошової форми та розглядаються як актив, що приносить дохід. В умовах капіталістичного суспільного ладу капіталом - цінністю, що приносить грошовий дохід у процесі товарного виробництва, - $\epsilon$ усі ресурси. Отже, людина також не стала винятком - такі її характеристики, як знання, здібності, навички, досвід, які за своєю сутністю не є товаром, грошима, набувають фрорми капіталу [11, с. 10].

Економічна сутність людського капіталу має різні визначення залежно від наукової позиції авторів і як поняття його трактують по-різному.

Заслуговує на увагу підхід до людського капіталу Сігайова А. О. та Шинкарюка О. В. Досліджуючи сутність і відмінності між поняттями «людський капітал» та «людський потенціал», вони прийшли до висновку, що людський капітал містить можливості індивіда, які за певних обставин реалізуються, а людський потенціал містить можливості, які реалізовані і які залишаються нереалізованими. Автори зазначають, що поняття «людський капітал» більше стосується економічної діяльності, а поняття «людський потенціал» $є$ більш соціальним та психологічним поняттям [12, с. 201].

3 позиції більшості вчених, людський капітал - це поєднання природних здібностей і людської енергії, здоров'я з набутими загальноосвітніми і професійними знаннями, досвідом, які повинні приносити дохід. Високоякісний людський капітал $€$ головним інтенсивним фактором розвитку інноваційної економіки, визначає здібності працівників ефрективно використовувати існуючу технологічну систему [5, с. 95].

$€$. Єгель зазначає, що в сучасних умовах людський капітал є головною цінністю суспільства і важливим фактором економічного зростання. Людський капітал як економічна категорія за багатьма ознаками схожий з активною частиною основного капіталу - він морально і фрізично зношується, вимагає поточного і капітального ремонтів, модернізації та заміни, переносить на вироблену продукцію частину своєї вартості [7, с. 82].

Таким чином, грамотний системний підхід до реалізації людського капіталу не тільки з боку 
участі людини в процесі виробництва як суб'єкта, який безпосередньо виробляє, але і з боку його інтелектуального потенціалу, тобто як творчого суб'єкта, здатний підвищити ефективність виробничих процесів, що виступає запорукою стабільності [6, с. 50].

В результаті вивчення наукової літератури можна зробити висновок, що спершу автори концепції людського капіталу сорормували уявлення про його відтворення як процес постійного продукування людських здібностей та їх використання суб'єктами у своїй діяльності для отримання доходу. Таке уявлення виникає, виходячи з розуміння людського капіталу як сукупності здібностей людини. Але при глибшому дослідженні відтворення людського капіталу акценти зміщуються на вивчення процесу продукування людських якостей, які розглядаються виключно через призму економічних інтересів суб'єктів економіки (людина, організація, держава).

Шахно А. Ю., узагальнюючи різні підходи до дослідження категорії «людський капітал», пропонує авторське визначення даного поняття. Людський капітал - це:

- соціально-економічна категорія, яка характеризує людину як складну систему відносин постіндустріального суспільства, яка в центрі всіх видів економічної діяльності, здатна до самоорганізації, оновлення, самовдосконалення та нестандартного мислення й виступає інтелектуальним, творчим фактором і ключовим ресурсом побудови соціально-інноваційної моделі розвитку економіки;

- сукупність природних якостей та сформованих й розвинутих в результаті власних та суспільних інвестицій продуктивних здібностей людини у вигляді знань, умінь, професійних навичок, досвіду, здоров'я, мотивації, мобільності, духовності, які здатні підвищувати продуктивність праці індивіда за рахунок використання й реалізації інтелектуальної, творчої, креативної компоненти, виступати джерелом доходів особистості в майбутньому та примножувати національне багатство країни;

- це форма капіталу, яка здатна створювати нову вартість у формі певних здібностей, знань, професійних навичок, досвіду, здоров'я та генерувати майбутні доходи [14, с. 64].

Ушенко Н. В. приходить до висновку, що людський капітал доцільно розуміти як складну системну економічну категорію, яка об'єднує структуру модулів конкретних економічних відносин 3 приводу людини як носія трудових функцій, знань, економічних інтересів та суспільного відтворення. Людський капітал як економічна категорія $€$ носієм системних відносин відтворювального процесу суспільства, в якому відбувається включення індивідуальної форми праці в суспільну. Це дозволяє органічно поєднувати людський капітал із загальним процесом відтворення капіталу як чинника та умови забезпечення динамічного розвитку. Тому на засадах системного підходу відтворення людського капіталу доцільно розглядати у взаємозв'язку всіх фаз цього процесу: формування, розподілу, розвитку, використання [13, с. 26].

Мельничук Д. П. дійшов висновку, що категорія «людський капітал» політекономічного змісту, адже свідчить про характер та закономірності розподілу національного доходу між різними верствами населення, статус та роль окремих соціальних прошарків, перспективи підвищення рівня та поліпшення якості життя працівників та їх сімей. Під людським капіталом пропонує розуміти економічний актив, що формується в результаті інвестицій шляхом набуття знань та доцільної видозміни продуктивних спроможностей індивіда (трудового колективу, суспільства в цілому) та є формою представлення останніх в ході трудової діяльності, яка забезпечує певний дохід учасникам інвестиційно-виробничого процесу. У площині «людського капіталу» - у розрізі здатності приносити дохід своєму власнику, впливаючи тим самим на якість життя його самого та суспільства в цілому [10, с. 27].

Корчагін Ю. А. доводить, що людський капітал в широкому сенсі - це інтенсивний продуктивний чинник економічного розвитку, розвитку суспільства і сім'ї, що включає освічену частину трудових ресурсів, знання, інструментарій інтелектуальної й управлінської праці, місце існування і трудової діяльності, що забезпечують ефективне і раціональне функціонування людського капіталу як продуктивного чинника розвитку. У вузькому сенсі, людський капітал - це інтелект, здоров'я, знання, якісна і продуктивна праця і життя [9].

Шульгіна Є. В. [15] використовує таку класифікацію людського капіталу:

- індивідуальний людський капітал;

- людський капітал фірми;

- національний людський капітал.

Виділяють чотири рівні людського капіталу:

- особистий (людський капітал окремих осіб);

- мікрорівень (людський капітал підприємств);

- мезорівень (людський капітал галузей, регіонів);

- макрорівень (сукупний людський капітал) [3, с. 165].

Нами узагальнено наявні трактування людського капіталу та встановлено, що існують два підходи до змістової характеристики людського капіталу.

Перший підхід - це структурно-функціональний підхід - змістова характеристика людського 
капіталу визначає компоненти структури людського капіталу, які є об'єктами керування і вимірювання.

Другий підхід - це управлінський підхід - змістова характеристика людського капіталу визначає його як систему показників (кількісних параметрів), які є об'єктами управління його структури (табл. 1).

На цій основі нами проведено актуальний аналіз 3 метою цілеспрямованого, стосовно компонентів структури і показників, керування і вимірювання людського капіталу.

\section{Змістова характеристика людського капіталу}

Таблиця 1

\begin{tabular}{|c|c|}
\hline \multicolumn{2}{|c|}{ ЛЮДСЬКИЙ КАПІТАЛ - ПІДХОДИ ДО ВИЗНАЧЕННЯ } \\
\hline $\begin{array}{c}\text { СТРУКТУРНО-ФУНКЦІОНАЛЬНИИ ПІДХІД - } \\
\text { КОМПОНЕНТИ СТРУКТУРИ } \\
\text { (об'єкТи керування і вимірювання) }\end{array}$ & $\begin{array}{l}\text { УПРАВЛІНСЬКИИ ПІДХІД - СИСТЕМА ПОКАЗНИКІВ } \\
\text { (кількісні параметри) }\end{array}$ \\
\hline 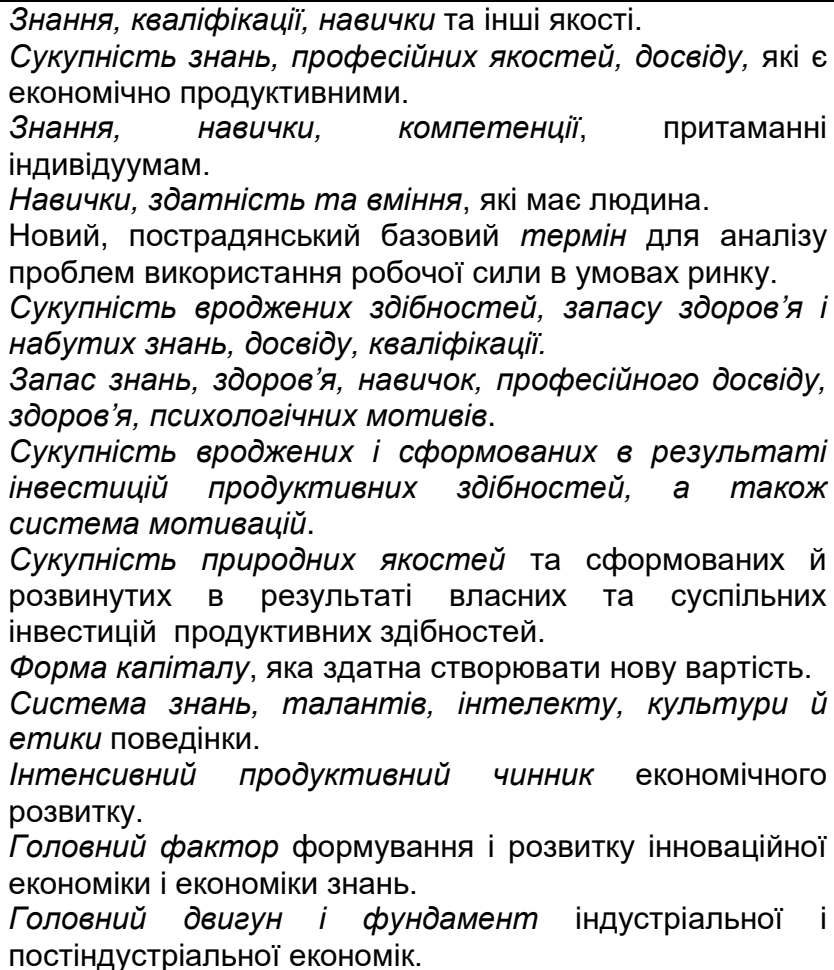 & 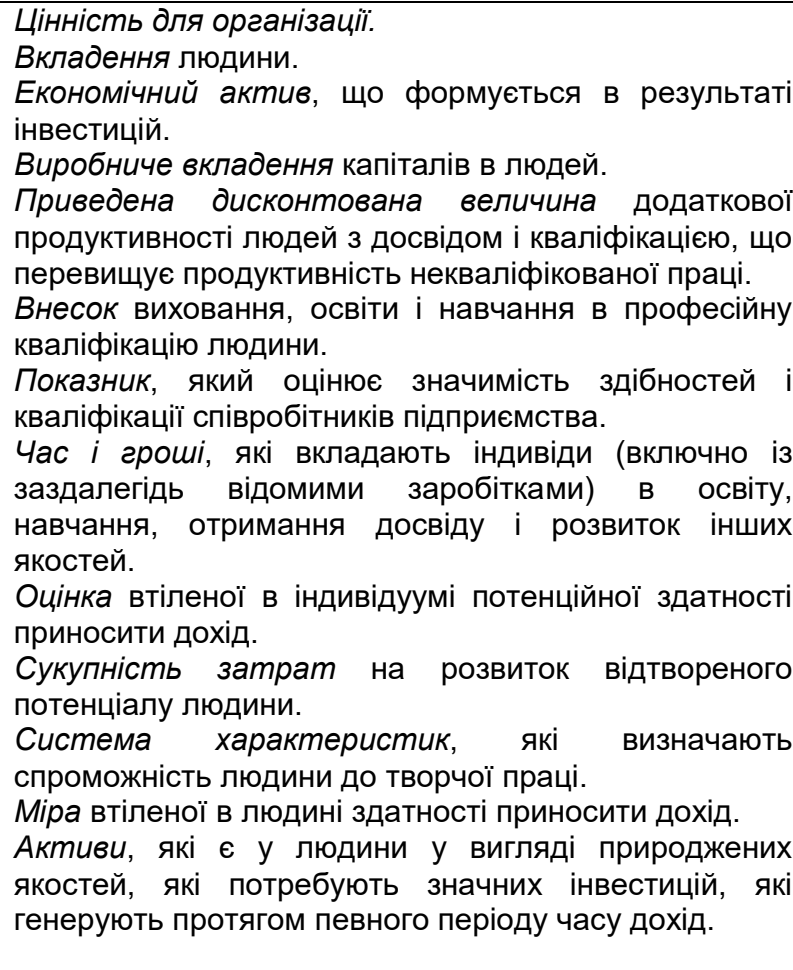 \\
\hline
\end{tabular}

Джерело: побудовано автором на основі $[1 ; 2 ; 3$, с. $165 ; 4$, с. 28; 5, с. 95; 6, с. 50; 7, с. 82; 8, с. 70; 9; 10 c. $27 ; 11$, c. $10 ; 12$, c. $201 ; 13$, c. $26 ; 14$, c. $64 ; 15 ; 16$, c. 20$]$

Отже, в результаті вивчення сутності поняття «людський капітал» встановлено наступне:

- людський капітал - це здатність приносити блага (співвідноситься 3 поняттям «робоча сила»);

- людський капітал - це запас (співвідноситься 3 поняттям «актив», який тимчасово не використовується);

- людський капітал - це ресурс (співвідноситься з поняттям «актив», який використовується);

-людський капітал - це потенціал (співвідноситься 3 поняттям «актив», який може використовуватися в обмежених обсягах? виходячи з використовуваної сукупності потенційної здатності або джерел потенційної здатності);

- людський капітал - це джерело доходу (співвідноситься з обсягом доходу);

- людський капітал - це особлива форма капіталу (виступає у вигляді взаємодії потреб і здібностей суб'єкта);

- людський капітал - це форма реалізації економічних відносин.

Серед науковців, що займаються дослідженням людського капіталу, через складність досліджуваної категорії, не сформувалося єдиної думки про компоненти структури людського капіталу та показники (кількісні параметри) які його характеризують. Однак, як справедливо зазначають К.І. Княгініна та Ю. Р. Хайрулліна, без системно-компонентного підходу, який відображає склад елементів структури людського капіталу та підсистем його походження, використання, неможливо цілеспрямовано керувати і вимірювати людський капітал [8, с. 70].

Компоненти структури людського капіталу, за структурно-функціонального підходу, потребують аспектизації. Аспектизація компонент структури людського капіталу можлива за трьома напрямками (табл. 2). 
Аспектизація компонент структури людського капіталу

Таблиця 2 (системно-компонентний підхід)

\begin{tabular}{|c|c|c|}
\hline \multicolumn{3}{|c|}{ Аспекти компонент структури людського капіталу } \\
\hline Соціальний: & Біологічний (вроджений): & Економічний: \\
\hline 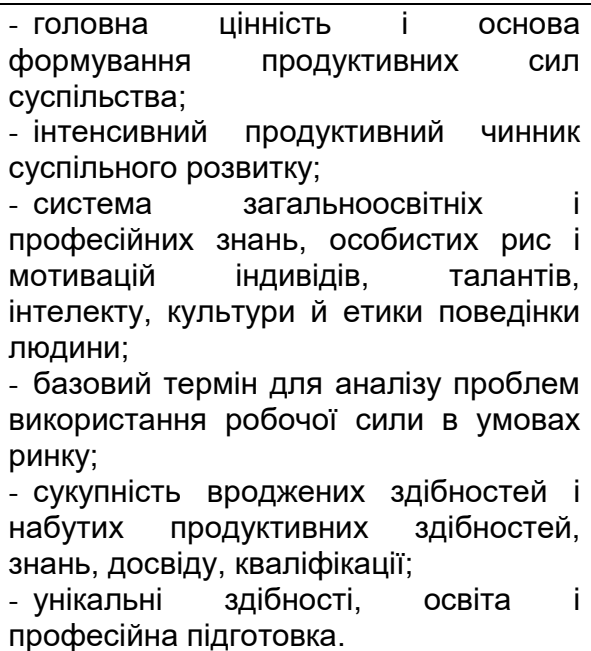 & $\begin{array}{l}\text { - сукупність природних якостей і } \\
\text { здібностей; } \\
\text { - сукупність людської енергії; } \\
\text { - запас здоров'я; } \\
\text { - емоційна стійкість; } \\
\text { - психологічні здібності. }\end{array}$ & $\begin{array}{l}\text { - інтенсивний продуктивний } \\
\text { чинник економічного розвитку; } \\
\text { - головний фактор формування і } \\
\text { розвитку інноваційної економіки і } \\
\text { економіки знань; } \\
\text { - головний двигун і фрундамент } \\
\text { індустріальної і постіндустріальної } \\
\text { економік; } \\
\text { - накопичені знання, вміння і } \\
\text { майстерність, професійні якості, } \\
\text { професійний досвід, компетенції, } \\
\text { кваліфікації, навички. }\end{array}$ \\
\hline \multicolumn{3}{|c|}{ Результативність: } \\
\hline $\begin{array}{l}\text { Вирішальні фактори: } \\
\text { - суспільного розвитку; } \\
\text { - суспільної організованості; } \\
\text { - суспільної ініціативності; } \\
\text { - суспільної ідентичності; } \\
\text { - розвитку суспільних систем } \\
\text { інститутів. }\end{array}$ & 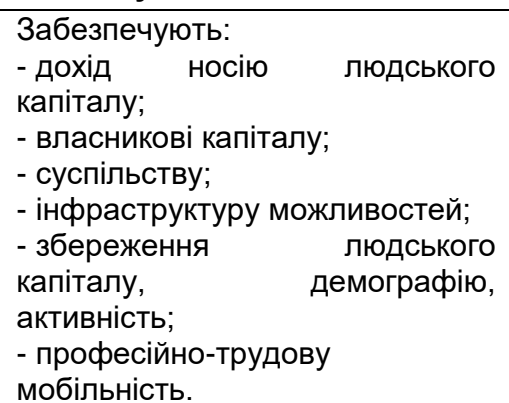 & $\begin{array}{l}\text { Визначають носія людського } \\
\text { капіталу: } \\
\text { - економічно продуктивним; } \\
\text { - як самостійну, універсальну } \\
\text { складову виробничого процесу; } \\
\text { - як основний елемент } \\
\text { продуктивних сил, що забезпечує } \\
\text { додаткову вартість продукту; } \\
\text { - як основний } \\
\text { виробництва. інститут }\end{array}$ \\
\hline
\end{tabular}

Джерело: побудовано автором на основі $[1 ; 2 ; 3$, с. $165 ; 4$, с. $28 ; 5$, с. 95; 6, с. 50; 7, с. 82; 8, с. 70; 9; 10 , c. $27 ; 11$, c. $10 ; 12$, c. $201 ; 13$, c. $26 ; 14$, c. $64 ; 15 ; 16$, c. 20$].$

Отже, одні вчені, трактуючи поняття «людський капітал», відмічають його характеристики, які забезпечують його соціальне значення, другі - біологічне, треті - економічне. В структурі людського капіталу виділяють знання, навички, здібності, компетенції, набуті індивідом у ході навчання й трудової діяльності та вроджені здібності, які підвищують розумову і фрізичну здатність працівника.

Висновки $з$ проведеного дослідження. Підсумовуючи, відзначимо, що, на наш погляд, у трактуванні терміну «людський капітал» необхідно дотримуватись системно-компонентного підходу, який визначає склад компонент (елементів) і аспектів компонент структури людського капіталу (підсистем), та системно-організаційного підходу, що розкриває внутрішню організацію людського капіталу та взаємовідношення утворюючих його компонентів, тобто ті, які були отримані біологічно, ті, які були отримані через формальне навчання, ті, які були отримані через вкладення, інвестиції в людину, що забезпечують накопичення певних якостей і здібностей.

\section{Література}

1. Becker G. The Human Capital: a Theoretical and Empirical Analysis with Special Reference to Education. New York : Columbia University Press, $1964 . \quad 265$ p. URL: https://www.academia.edu/35396287/HUMAN_CAPITAL_A_Theoretical_and_Empirical_Analysis_with_S pecial_Reference_to_Education_THIRD_EDITION (дата звернення: 28.02.2020).

2. Schultz $\bar{T} . \bar{W}$. Investment in Human Capital: the Role of Education and of Research. New York : FreePress, $1971 . \quad 272 \quad$ p. $\quad 2 R$ : https://academic.oup.com/ajae/articleabstract/53/4/692/83856?redirectedFrom=fulltext (дата звернення: 28.02.2020).

3. Амосов О., Дєгтяр А. Формування людського капіталу в умовах інноваційної економіки: методологічний аспект. URL: http://www.kbuapa.kharkov.ua/e-book/putp/2011-3/doc/3/08.pdf (дата звернення: 28.02.2020). 
4. Беккер Г. С. Человеческое поведение: экономический подход. Избранные труды по экономической теории / пер. с англ. под науч. ред. Р. И. Капелюшникова. Москва, 2003. 672 c. URL: https://id.hse.ru/books/25342826.html (дата звернення: 02.04.2020).

5. Глухова 3. В., Куклина Е. С. Человеческий капитал и человеческий потенциал: подходы к оценке. Вестник СибАДИ. 2013. № 2(30). С. 95-100.

6. Детков А. А., Бонченкова В.А., Жихалов П. С., Гусева С. Ю. Человеческий капитал как фактор эфффективности производительных сил. Научный альманах. 2017. № 6-1(32). C. 50-53. URL: https://ukonf.com/doc/na.2017.06.01.pdf (дата звернення: 28.02.2020).

7. Егель Е. А. Человеческий капитал: теория и практика. Экономический журнал. 2006. № 13. C. 82-86.

8. Княгинина К. И., Хайруллина Ю. Р. Человеческий капитал как социологическая категория. URL: https://www.elibrary.ru/item.asp?id=29742488 (дата звернення: 28.02.2020).

9. Корчагин Ю. А. Широкое понятие человеческого капитала. URL: http://www.lerc.ru/?part=articles\&art=3\&page=22 (дата звернення: 28.02.2020).

10. МельничукД.П. Людський капітал: пріоритети модернізації суспільства у контексті поліпшення якості життя населення : автореф. дис. ... д-ра екон. наук : 08.00.07. Київ, 2015. 43 с.

11. Розвиток людського капіталу: на шляху до якісних реформ / Центр Разумкова. Київ : Видавництво $\quad$ «Заповіт», $2018 . \quad 368 \quad$ c. http://razumkov.org.ua/uploads/article/2018_LUD_KAPITAL.pdf (дата звернення: 20.04.2020).

12. Сігайов А. О., Шинкарюк О. В. «Людський потенціал» та «людський капітал» як категорії механізму управління національним господарством. Формирование рыночных отношений 8 Украине. 2015. № 5(168). C. 201-211. URL: https://cyberleninka.ru/article/n/lyudskiy-potentsial-talyudskiy-kapital-yak-kategoriyi-mehanizmu-upravlinnya-natsionalnim-gospodarstvom (дата звернення: 02.04.2020).

13. Ушенко Н. В.Науково-методологічні основи державного регулювання відтворення людського капіталу України : авторефр. дис. ... д-ра екон. наук : 08.00.03. Київ, 2009. 35 с.

14. Шахно А. Ю. Моделі розвитку та державне регулювання людського капіталу в умовах глобалізації : дис. ... д-ра екон. наук : 08.00.03 / Нац. ун-т «Львівська політехніка». Львів, 2019. $561 \mathrm{c}$.

15. Шульгина Е. В. Развитие человеческого потенциала. URL: http://hdirussia.ru/210.htm (дата звернення: 28.02.2020).

16. Яловий Г. К. Теорія людського капіталу як методологія формування інноваційної системи. Економічний вісник НТУУ «КПІ». 2015. № 12. C. 20-28. URL: http://ev.fmm.kpi.ua/article/view/43884 (дата звернення: 28.02.2020).

\section{References}

1. Becker, G. (1964), The Human Capital: a Theoretical and Empirical Analysis with Special Reference to Education, Columbia University Press, New York, USA, 265 p., available at: https://www.academia.edu/35396287/HUMAN_CAPITAL_A_Theoretical_and_Empirical_Analysis_with_S pecial_Reference_to_Education_THIRD_EDITION (access date February 28, 2020).

2. Schultz, T.W. (1971), Investment in Human Capital: the Role of Education and of Research, FreePress, New York, USA, 272 p., available at: https://academic.oup.com/ajae/articleabstract/53/4/692/83856? redirectedFrom=fulltext (access date February 28, 2020).

3. Amosov, O. and Diehtiar, A. (2011), "Formation of human capital in the conditions of innovation economy: methodological aspect", available at: http://www.kbuapa.kharkov.ua/e-book/putp/20113/doc/3/08.pdf (access date February 28, 2020).

4. Bekker, G.S. (2003), Chelovecheskoe povedenie: ekonomicheskiy podkhod. Izbrannye trudy po ekonomicheskoy teorii [Human Behavior: Economic Approach. Selected works on economic theory], Translated by R.I. Kapeliushnikov, Moscow, Russia, 672 p., available at: https://id.hse.ru/books/25342826.html (access date April 02, 2020).

5. Glukhova, Z.V. and Kuklina, E.S. (2013), "Human capital and human potential: approaches to evaluation", Vestnik SibADI, no. 2(30), pp. 95-100.

6. Detkov, A.A., Bonchenkova, V.A., Zhikhalov, P.S. and Guseva, S.Yu. (2017), "Human capital as a factor of efficiency of productive forces", Nauchnyy almanakh, no. 6-1(32), pp. 50-53, available at: https://ukonf.com/doc/na.2017.06.01.pdf (access date February 28, 2020). 82-86.

7. Egel, E.A. (2006), "Human capital: theory and practice", Ekonomicheskiy zhurnal, no. 13, pp.

8. Kniaginina, K.I. and Khayrullina, Yu.R. (2017), "Human capital as a sociological category", available at: https://www.elibrary.ru/item.asp?id=29742488 (access date February 28, 2020).

9. Korchagin, Yu.A. (2009), "Wide concept of human capital", available at: http://www.lerc.ru/?part=articles\&art=3\&page $=22$ (access date February 28, 2020).

10. Melnychuk, D.P. (2015), "Human Capital: priorities of modernization of society in the context 
of improving the quality of life of the population", Thesis abstract of Dr.Sc. (Econ.), 08.00.07, Instytut demohrafii ta sotsialnykh doslidzhen im. M.V. Ptukhy NAN Ukrainy, Kyiv, Ukraine, 43 p.

11. Razumkov Centre (2018), Rozvytok liudskoho kapitalu: na shliakhu do yakisnykh reform [Human capital development: on the way to qualitative reforms], Vyd-vo "Zapovit", Kyiv, Ukraine, 368 p., available at: http://razumkov.org.ua/uploads/article/2018_LUD_KAPITAL.pdf (access date April 20, 2020).

12. Sihaiov, A.O. and Shynkariuk, O.V. (2015), "'Human Potential" and "Human Capital" as a category of the mechanism of management of the national economy", Formirovanie rynochnykh otnosheniy v Ukraine, no. 5(168), pp. 201-211, available at: https://cyberleninka.ru/article/n/lyudskiypotentsial-ta-lyudskiy-kapital-yak-kategoriyi-mehanizmu-upravlinnya-natsionalnim-gospodarstvom (access date April 02, 2020).

13. Ushenko, N.V. (2009), "Scientific and methodological basis of state regulation of human capital reproduction of Ukraine", Thesis abstract of Dr. Sc. (Econ.), 08.00.03, Kyiv, Ukraine, 35 p.

14. Shakhno, A.Yu. (2019), "Models of development and state regulation of human capital in the conditions of globalization", Diss. of Dr. Sc. (Econ.), 08.00.03, Nats. un-t "Lvivska politekhnika", Lviv, Ukraine, $561 \mathrm{p}$.

15. Shulgina, E.V. (2020), "Development of human potential", available at: http://hdirussia.ru/210.htm (access date February 28, 2020).

16.Yalovyi, H.K. (2015), "Theory of Human Capital as a methodology for the formation of an innovative system", Ekonomichnyi visnyk NTUU "KPl", no. 12, pp. 20-28, available at: http://ev.fmm.kpi.ua/article/view/43884 (access date February 28, 2020). 